\title{
Pengembangan Model ATIK untuk Meningkatkan Kompetensi Menggambar pada Anak Taman Kanak- Kanak
}

Sri Watini ${ }^{1 凶}$

Pendidikan Guru Pendidikan Anak Usia Dini, Universitas Panca Sakti Bekasi

DOI: $\underline{10.31004 / \text { obsesi.v5i2.899 }}$

\begin{abstract}
Abstrak
Kemampuan menggambar merupakan salah satu kemampuan yang dapat mengembangkan daya imajinasi anak. Faktanya kemampuan tersebut berkurang bahkan hilang ketika anak memasuki jenjang Sekolah Dasar. Penelitian ini bertujuan untuk mengembangkan model ATIK dalam meningkatkan kompetensi menggambar pada Taman Kanak-kanak (TK) di Kota Bekasi. Hal ini disebabkan karena banyak terjadi kegagalan dalam membelajarkan anak TK pada kemampuan menggambar, dibuktikan dengan hilangnya kompetensi menggambar anak pada saat di Sekolah Dasar (SD). Metode yang digunakan dalam penelitian ini adalah metode penelitian dan pengembangan (R\&D) dengan analisis data model Borg \& Gall. Instrumen yang digunakan dalam penelitian ini berupa angket. Adapun lembaga TK yang dipilih adalah TK Putra XII, TK Amira, TK Widya Bakti dan TK Baiturahim. Hasil penelitian dan pengembangan berdasarkan pada uji efektivitas, maka Model ATIK ini efektif dalam mengembangkan kompetensi menggambar pada anak TK.
\end{abstract}

Kata Kunci: model atik; kompetensi menggambar; tk

\begin{abstract}
The ability to draw is one of the abilities that can develop children's imagination. The fact is that this ability decreases and even disappears when the child enters the elementary school level. This study aims to develop the ATIK Model in improving drawing competencies in Kindergarten in Bekasi City. This is due to the many failures in teaching drawing skills to kindergarten. Evidenced by loss of competence in drawing at elementary school. The method used in this research is the Research and Development Method (R\&D) with data analysis by the Borg \& Gall model. The instrument used in this study was a questionnaire. The institutions chosen were TK Putra XII, TK Amira, TK Widya Bakti and TK Baiturahim. The results of research and development are based on effectiveness tests, so the ATIK Model is effective in developing drawing competencies in Kindergarten.
\end{abstract}

Keywords: atik model; drawing competencies; kindergarten.

Copyright (c) 2020 Sri Watini

$\triangle$ Corresponding author:

Email Address : srie.watini@gmail.com (Jakarta, Indonesia)

Received 20 November 2020, Accepted 25 November 2020, Published 5 December 2020 


\section{PENDAHULUAN}

Pendidikan dalam implementasinya memiliki makna yang luas. Banyak potensi yang dapat dikembangkan pada peserta didik. Sudah sepantasnya(Tahel \& Ginting, 2018) jika anak nantinya dapat hidup sesuai dengan bakat dan talentanya masing-masing tanpa unsur paksaan dari lingkungan. Pendidik sebagai fasilitator dan motivator untuk mengembangkan potensi anak secara optimal melalui bimbingan dan arahan agar anak mencapai kehidupan yang merdeka. Hal ini selaras dengan hakikat pendidikan yang diungkapkan oleh KH Dewantara di mana Pendidikan harus melahirkan anak-anak yang hidup dengan merdeka. Pendidikan seperti ini haruslah dimulai dari sejak pendidikan anak usia dini.

TK adalah lingkup pendidikan anak usia dini pada jalur pendidikan formal. Anak TK ini adalah anak-anak yang telah siap untuk memasuki jenjang SD. TK merupakan bagian Pendidikan Anak Usia Dini (PAUD) di jalur formal yang memiliki dua kelompok usia yaitu usia 4-5 tahun dalam TK kelompok A dan usia 5-6 tahun untuk kelompok B (Watini, 2019a). The nature of education is also "Fostering Effort aimed for children since they were born up to the age of 0-6 years old (Watini, 2020). Pendidikan TK merupakan salah satu bentuk pendidikan anak usia dini yang memiliki peranan sangat penting untuk mengembangkan kepribadian anak serta mempersiapkan mereka untuk memasuki jenjang pendidikan selanjutnya (Masitoh dkk, 2005). Pembelajaran yang nampak dan menarik bagi anak TK adalah menggambar (Suryana, 2016). Hal ini dibuktikan begitu senangnya mereka menggambar dan menghabiskan lembaran-lembaran kertas gambar edukasi yang menyenangkan.

Kenyataannya pembelajaran menggambar tidak mampu mengembangkan bakat anak dengan baik. Mulai SD kelas 4 bakat menggambar itu mulai hilang dan luntur begitu saja. Hal ini disebabkan oleh beberapa faktor antara lain: bakat anak yang tidak tersalurkan dengan baik, bakat anak kurang terakomodir dengan baik, media, metode maupun model pembelajaran yang dianggap kurang cocok dengan perkembangan usia anak TK, persepsi pengembangan bakat anak yang terkesan sangat mahal, proses pembelajaran yang belum tepat, kurang bermakna dan kurang menghargai pada bakat bahkan ketidaktahuan cara mengidentifikasi dan sebagainya (Ditha Prasanti \& Dinda Rakhma Fitriani, 2018).

Berdasarkan hasil survey pada anak TK, ditemukan masih banyak anak yang tidak paham dalam pembelajaran menggambar dengan baik dan benar. Hal ini dapat dilihat ketika meminta anak membuat gambar, terkadang anak tidak paham awal membuat apalagi memadukan warna. Hal ini tentunya menjadi perhatian bagi pendidik, agar dapat tidak hanya mengajarkan menggambar tetapi juga diharapkan mampu mengembangkan bakat menggambarnya dengan baik. Bahkan tak jarang anak-anak dimarahi saat mengikuti lomba menggambar karena karya yang dihasilkan tidak sesuai dengan keinginan orang tua atau pendidik. Untuk itulah maka penelitian ini dalam rangka mengembangkan kemampuan menggambar pada anak TK melalui "Model ATIK". ATIK adalah singkatan dari Amati, Tiru. Kerjakan (ATIK).

Model diartikan sebagai kerangka konseptual yang digunakan sebagai pedoman dalam melakukan suatu kegiatan (Abdul Majid, 2013). Model atau konstruksi merupakan ulasan teoritis tentang suatu konsepsi dasar (Arifin, 2011). Model yang dimaksud dalam penelitian ini adalah Model Pembelajaran. Menurut Dewey dalam Joyce dan Well (1986) mendefinisikan model pembelajaran sebagai "a plan or pattern that we can use to design face to face teaching in the classroom or tutorial setting and to shape instructional material" artinya model adalah suatu rencana atau pola yang dapat kita gunakan untuk merancang tatap muka di kelas atau pembelajaran tambahan di luar kelas dan untuk menajamkan materi pengajaran (Abdul Majid, 2013). A model of teaching is a way of building a nurturant and stimulating ecosystem within which the student learn by interacting with its components (Bruce R. Joyce, Bruce R Joyce, 2015). Dengan mengimplementasikan model pembelajaran yang tepat maka 
akan sangat mempengaruhi pada kualitas hasil belajar anak. Model ini akan menjadi acuan dalam proses perencanaan pembelajaran, mengkolaborasikan komponen kurikulum, merancang materi dan bahan ajar, strategi Teknik dan taktik serta rancangan media yang akan digunakan dalam meningkatkan kemampuan menggambar pada anak.

Model ATIK merupakan model pembelajaran menggambar yang dikembangkan dari Model Experiental Learning Theory (ELT) dan Model Pembelajaran tidak langsung. Model ELT dikembangkan oleh David Kolb. Experiental Learning Theory adalah suatu model proses belajar mengajar yang mengaktifkan pembelajar untuk membangun pengetahuan dan keterampilan melalui pengalaman secara langsung (Abdul Majid, 2013). Model pembelajaran tidak langsung sering disebut model pembelajaran inkuiri, pemecahan masalah, pengambilan keputusan dan penemuan (Abdul Majid, 2013). Kolb`s Model of experiental learning proposes that knowledge is created through transformative experiences, "This model is cydical and has four phases, including two modes of acguiring experience (concrete experience and abstract conceptualization) and two modes of transforming experience (reflective observation and active experimentation) (Patricia Giardiello, Joanne McNulty, 2013).Experiental learning an overarching term used to classify several different forms of learning approaches, including problem and inquiry-based learning(Carina Girvan, Claire Conneely, 2016).

Robetson dan Lang dalam Suryadi (2005:14) mengemukakan, "Pembelajaran tidak langsung memiliki karakteristik salah satunya adalah Menuntut keterlibatan anak secara aktif dalam melakukan observasi, investigasi, pengambilan kesimpulan dan pencarian alternative solusi dan (Abdul Majid, 2013)Thus in an inquiry-based classroom learners (1) are engaged in scientifically oriented questions. (2) give priority to evidence, (3) formulate explanations from evidence (4) evaluate their explanations in light of alternative explanations and (5)communicate and defend their proposed explanations (Loyd Mataka, 2020).student use their exiting understandings and experiences too construct new knowledge (Loyd Mataka, 2020). Dengan mengkolaborasikan model ELT dengan Model pembelajaran tidak langsung yang lebih dikenal dengan model Inkuri ini maka diperoleh model baru dengan nama model ATIK.

Amati merupakan suatu proses kegiatan untuk melihat atau memperhatikan suatu obyek, kejadian atau peristiwa yang ada di sekitarnya. Amati merupakan kata dasar dari mengamati ataupun pengamatan. Dalam pendidikan anak usia dini pengamatan adalah hal yang paling penting dalam kehidupan anak. Observation is crucial to understanding and assessing young children's learning...Observation which are realy reflected upon are a wasted effrt. It is only when practiiopners seek to understand the meaning behind what they have sees that thereal worth of observational practices are realized (Patricia Giardiello, Joanne McNulty, 2013). Hal ini disebakan karena anak usia dini adalah anak yang sedang berkembang keingintahuannya terhadap peristiwa apapun yang terjadi di lingkungannya.

Melalui semua alat indera yang dimiliki anak melakukan pengamatan terhadap semua kejadian ada di sekitarnya. Menurut People menyatakan, "75\% pengetahuan manusia diperoleh melalui pengamatan (Hartati, 2005). Peaget dalam (Dimyati dan Mujiono) berpendapat bahwa pengetahuan dibentuk oleh individu dengan cara melakukan interaksi secara terus menerus dengan lingkunganya yang selalu mengalami perubahan.(Watini, 2019b)Carrying out and recording observations of young children has a longheld traditionin early childhood practice (Patricia Giardiello, Joanne McNulty, 2013). Dari kegiatan pengamatan tersebut anak akan belajar tentang konsep, bentuk, model dan bahkan mampu menciptakan simbol-simbol dari hasil persepsinya sendiri. Bredekamp \& Copple (1997) menyatakan, " semua belajar bagi anak dimulai dari persepsi: melihat, mendengar, menyentuh, merasa dan mencium (Masitoh, 2005).

Perkembangan imitation menurut Peaget, adalah suatu kemampuan melakukan kembali perilaku yang dicontohkan (Dkk, 2011). Anak akan melakukan peniruan atau imitasi pada apa yang dilihat, didengar dan dirasakan. Peniruan dalam tahapan konseptual dapat membentuk pengertian, karena dengan perilaku imitasi di mana anak sebelumnya tidak mengerti dan setelah anak melakukan perilaku imitasi anak mulai mengerti apa yang 
Pengembangan Model ATIK untuk Meningkatkan Kompetensi Menggambar pada Anak Taman Kanak-Kanak DOI: 10.31004/obsesi.v5i2.899

dilakukannya menyenangkan atau tidak menyenangkan yaitu mendapatkan respon. positif atau negatif (Abubakar Baraja, 2008). Bandura dan Walters (1963) dalam teori belajar social menjelaskan bahwa tingkah laku dapat ditiru atau dipelajari melalui "melihat" (Abubakar Baraja, 2008).

Kegiatan meniru pada anak usia dini akan menjadi kebiasaan dan akan dilakukan secara terus menerus jika oleh lingkungan diberikan respon dengan baik bahkan diberikan reward. Imitation theory is that it makes the social process something apart from the life-proces (CA Ellwood, 1901). Imitasi bagi anak usia merupakan suatu cara bagaimana mereka menirukan aktivitas atau kegiatan yang dilakukan oleh orang-orang di lingkungan yang tentunya akan mempengaruhi kehidupan anak. The imitation theory of the social process something apart from the life-process is abstract; it makes no sufficient reference to the concrete conditions of uman life to give a faithfull description of social reality.(CA Ellwood, 1901)

Doing dalam active experimentation menurut Kolb (Abdul Majid, 2013), anak ditempatkan pada situasi-situasi nyata dalam proses pembelajaran. Dengan mengerjakan sesuatu maka seseorang akan mendapatkan suatu keterampilan, pengetahuan dan pengalaman dari suatu peristiwa atau kejadian. Dalam konsep Model ELT (Experimental Learning Theory) ada 4 tahap dalam proses pembelajaran yaitu Concrete Experience (CE), Reflection Observation (RO), Abstract Conceptualization (AC) dan Active Experimentation (AE) (Abdul Majid, 2013). This method of learning encourages children and provides opportunities encourages children and provides opportunities for children to experiment on their own. His is in accordance with the results of Maryam 's research, a lecturer states that there are three stages of the child to facilitate the entry of information, namely, listening, writing or drawing and view and advance the experiment itself(Watini \& Efendy, 2018).

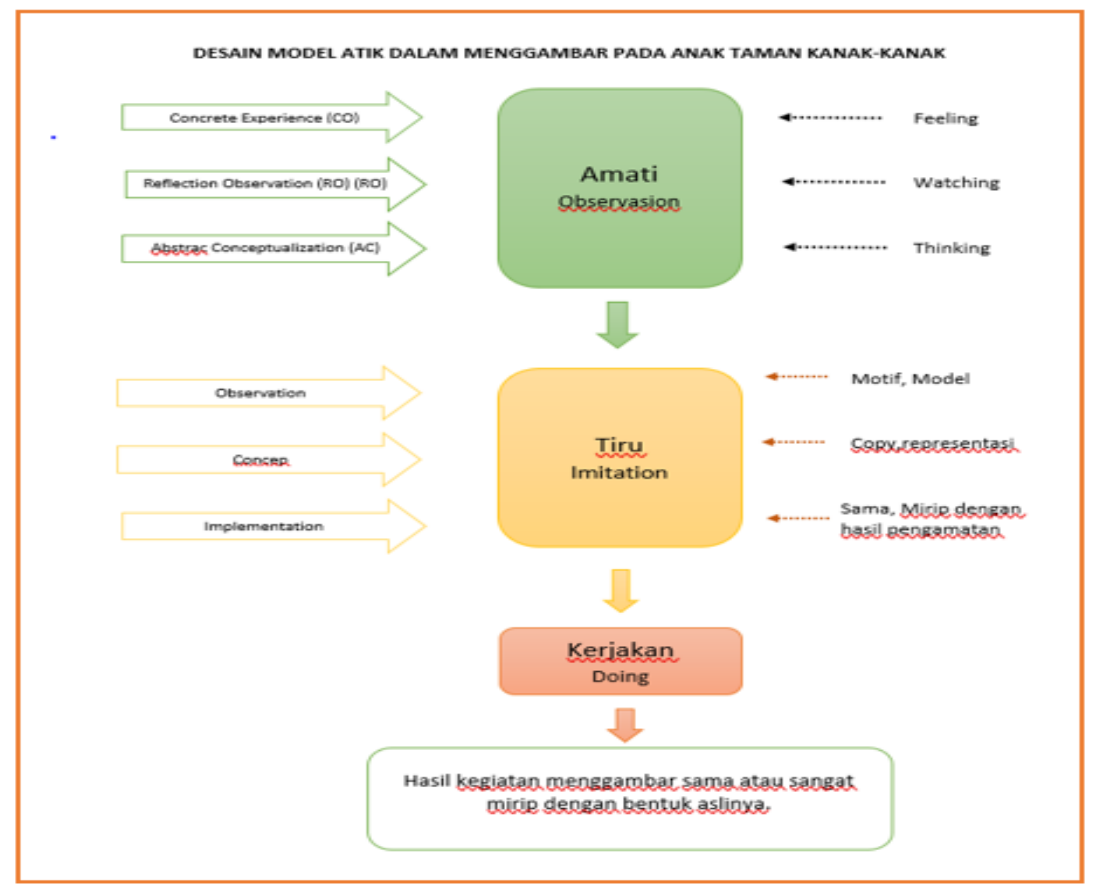

Gambar 1 Desain “ Model Atik”

Kompetensi merupakan suatu kemampuan yang terukur dan dapat diamati. Bruce (1995), "A competence is being to perform whole work roles to the standards expected in employment is real working environment, while standard are the means by which the model of competence a specified in the current occupational context."(Loeloek Endah Poerwati, 2013). Dalam hal ini kompetensi sebagai kemampuan untuk melaksanakan tugas dalam suatu pekerjaan yang memiliki standar tertentu dalam suatu lingkungan. Menurut Mc. Ashan 
(1981), "mengemukakan bahwa kompetensi ..."is a knowledge, skills," and abilities or capabilities that a person achiees, which become part of his or her being to the exent he or she can satisfactorily perform particular cognitive, affective, and psychomotor behaviors,"(Mulayasa, 2003).

Menurut Hajar Paramadhi (2011), menggambar adalah membuat gambar. Kegiatan ini dilakukan dengan cara mencoret, menggores, menorehkan benda tajam ke benda lain dan memberi warna, sehingga menimbulkan gambar." Gambar (drawing) menurut Pangarso dalam (Prasetyo, 2017) merupakan sebuah karya seni yang mempresentasikan suatu objek secara detail, dengan media pensil, pena dan sebagainya. Dalam arti menggambar adalah kegiatan mempresentasikan suatu objek secara detail, dengan media pensil, pena dan sebagainya. Morkeh (2011) echoes that drawing was the first means of expression and representation invited by man and it is still extremely valid both as an srtistic representation of reality and as a means of expressing pure imagination(Eshun et al., 2018)

Untuk itu dapat dipahami begitu pentingnya proses pembelajaran menggambar pada anak usia dini apalagi usia Taman-Kanak-kanak, karena usia tersebut adalah usia untuk mempersiapkan diri memasuki jenjang Sekolah Dasar. Maka diharapkan dengan adanya model ATIK ini dapat menjadi motivasi bagi anak dalam belajar menggambar sehingga dapat meningkatkan kemampuan anak dalam menggambar.

\section{METODOLOGI}

Metode dalam penelitian ini menggunakan R \& D. Definisi R \& D secara sederhana adalah metode penelitian yang secara sengaja, sistematis, bertujuan atau diarahkan untuk mencari, menemukan, merumuskan, memperbaiki, mengembangkan, menghasilkan, menguji keefektifan produk, model, metode/strategi/cara/jasa, prosedur tertentu yang lebih unggul, baru, efektif, efisien, produktif dan bermakna (Nusa Putra, 2013). Penelitian ini menggunakan instrument angket dan dianalisis secara deskriptif kuantitatif dengan 10 langkah dalam penelitian R \& D menurut Borg \& Gall (gambar 2)

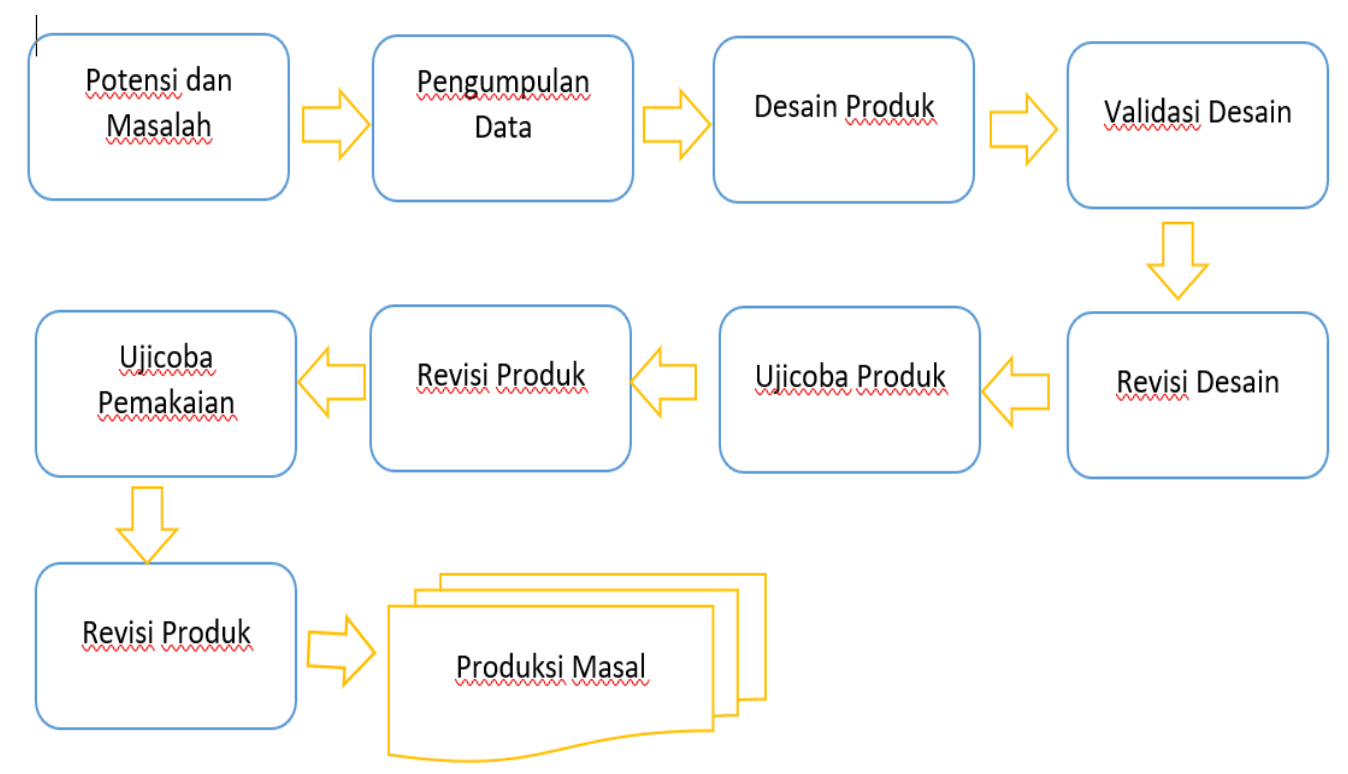

Gambar 2. Model penelitian R \& D menurut Borg \& Gall (Sugiyono, 2008)

\section{HASIL DAN PEMBAHASAN}

Dalam proses penelitian ini, peneliti melakukan uji coba. Peneliti melakukan uji coba kelompok kecil. Jika mengalami perubahan yang bagus maka dilakukan uji coba kelompok besar. Hasil uji coba kelompok kecil dapat dilihat pada tabel 1. 
Pengembangan Model ATIK untuk Meningkatkan Kompetensi Menggambar pada Anak Taman Kanak-Kanak DOI: $10.31004 /$ obsesi.v5i2.899

\section{Tabel 1: Uji Coba Kelompok Kecil}

\begin{tabular}{cccccccc}
\hline Variabel & $\mathrm{N}$ & Mean & $\begin{array}{c}\text { Std. } \\
\text { Deviation }\end{array}$ & t-value & df & $p$-Value & Keterangan \\
\hline Pre-test & 29 & 1.241379 & 0.510964 & $|-26.291|$ & 28 & $<2.2 \times 10^{-16}$ & Signifikan \\
Post-test & 29 & 3.724138 & 0.454859 & & & & \\
\hline
\end{tabular}

Dari hasil uji efektivitas uji coba pada kelompok kecil dengan jumlah 29 anak pada TK Putra XII dengan uji t berpasangan (paired $t$-test) diketahui bahwa nilai $t_{\text {hitung }}=|-26.291|$ $>t_{\text {tabel }}=2.048407\left(\mathrm{p}\right.$-value $\left.=<2.2 \times 10^{-16}\right)$ maka dapat disimpulkan bahwa terdapat perbedaan yang bermakna secara statistik antara pretest dan posttest. Artinya, terdapat perbedaan sebelum dan setelah diimplementasikannya Model ATIK dalam mengembangkan kompetensi menggambar pada kelompok kecil.

Berdasarkan hasil uji coba diatas, dapat dikatakan bahwa model ATIK dapat digunakan dalam proses menggambar pada Taman Kanak-Kanak. Karna peneliti sudah melakukan uji coba kecil berjasil maka selanjutnya peneliti melakukan uji coba kelompok besar. Hal ini dapat di lihat pada tabel 2.

Tabel 2: Uji Coba Kelompok Besar

\begin{tabular}{cccccccc}
\hline Variabel & $\mathrm{N}$ & Mean & Std. Deviation & $\mathrm{t}$-value & $\mathrm{df}$ & $p$-Value & Keterangan \\
\hline Pre-test & 118 & 1.567797 & 0.619882 & $|-38.679|$ & 117 & $<2.2 \times 10-16$ & Signifikan \\
Post-test & 118 & 3.635593 & 0.533738 & & & & \\
\hline
\end{tabular}

Pada uji coba kelompok besar dengan jumlah 118 terdiri dari gabungan TK Amira, TK Widia Bakti, TK Baiturahim, dengan uji $\mathrm{t}$ berpasangan (paired $t$-test) diketahui bahwa nilai $t_{\text {hitung }}=|-38.679|>t_{\text {tabel }}=1.980448\left(p\right.$-value $\left.=<2.2 \times 10^{-16}\right)$ maka dapat disimpulkan bahwa terdapat perbedaan yang bermakna secara statistik antara pretest dan posttest. Artinya, terdapat perbedaan sebelum dan setelah diimplementasikannya Model "ATIK" dalam mengembangkan kompetensi menggambar pada kelompok besar. Maka dapat disimpulkan, Model "ATIK" dikatakan efektif dalam meningkatkan kompetensi menggambar pada anak TK di Kota Bekasi.

Dalam proses penelitian menggunakan model ATIK, anak tetap membuat gambar sesuai dengan kebebasannya namun tetap dengan gambar asli yang sudah disiapkan guru. Peneliti memberi penghargaan kepada anak tersebut bahwa gambarnya bagus. Peneliti mewawancari anak ini kenapa gambar tangan yang dibuat. Ada beberapa pilihan yang diberikan guru dalam memilih gambar seperti ada gambar bunga, gambar sampah, banjir, dan sebagainya. Makna yang diambil dari anak adalah dari kecil sudah dibiasakan disiplin sudah besar menjadi biasa hal inilah perlu kita kembangkan demi masa depan bangsa. Keberhasilan pendidikan, tergantung pada pendidik usia dini. Sebelum masuk sekolah dasar anak harus diberi pendidikan yang tepat dan disiplin, maksudnya pengaruh yang sesuai dengan perkembangannya.

Ada beberapa kegiatan yang mendukung penerapan model ATIK di TK Kota Bekasi yang diperhatikan peneliti adalah: 1) Menyediakan bahan untuk menggambar, seperti kertas atau buku gambar khusus, atau buku mewarnai, 2) Menyediakan gambar-gambar yang menarik dan disukai anak, 3) Mengajarkan konsep tentang teknik. Misal, tebal, tipis, lebar, sempit, gelap, terang, sudut, bentuk, kontur, dan sebagainya, 4) member apresiasi terhadap hasil karya anak, 5) Memberikan kesempatan untuk anak memilih subyek yang ingin ia gambar dan lembar mewarnai yang ia inginkan.

Implementasi "Model ATIK" proses pembelajaran menggambar dari hasil penelitian terbukti dapat meningkatkan kompetensi menggambar pada anak Taman Kanak-kanak dengan baik dan mejadi kebutuhan yang sangat penting juga untuk perkembangan motorik halus anak. Sesuai dengan pendapat (Tahel \& Ginting, 2018) bahwa dengan menggambar 
dapat meningkatkan imajianasi dan motorik halus anak dalam belajar. Dengan menggambar kreatifitas anak, hal ini dapat dilihat ketika anak mncocokkan warna maupun pemilihan warna yang menarik.

Menggambar ternyata bukan hanya kegiatan yang menyenangkan bagi anak-anak. Banyak manfaat yang bisa didapatkan anak dari coretan tangannya. Dalam perkembangannya, menggambar pun dijadikan sebagai art therapy untuk kesehatan mental dan merangsang otaknya. Bahkan dengan menggambar anak usia dini dapat membuat seseorang anak lebih fokus karena ada koordinasi antara mata dan gerakan tangan. Lebih dari itu, anak pun akan lebih peka terhadap lingkungan sekitar, memiliki empati, dan meningkatkan intuisi. Selain mengembangkan kreativitas anak, menggambar juga bisa dijadikan media anak mengungkapkan perasaan atau emosinya. Mereka akan lebih rileks setelah mencurahkan isi hatinya lewat goresan tangan (Hajar Paramadhi, 2011).

Meningkatnya kompetensi menggambar anak juga dapat dilihat dari beberapa indikator hasil gambar antara lain: anak dapat menghasilkan gambar sesuai dengan dengan bentuk aslinya, anak dapat membuat hasil gambar yang beragam dan tidak monoton sesuai dengan hasil pengamatan, meningkatkan motivasi dalam menggambar karena mendapatkan hasil yang lebih baik dengan menerapkan model baru, anak dapat menggambar sesuai dengan minat dan obyek yang menjadi pusat perhatiannya, anak merasa nyaman dan merdeka dalam menggambar tanpa unsur paksaan dari lingkungan terkait dengan apa yang mereka ingin kerjakan dalam menggambar, dapat meningkatkan kecerdasan motorik halusnya dengan baik, meningkatkan daya ingat atau memori pada apa yang digambar berdasarkan pada hasil pengamatan, meningkatkan daya kreatif dan inovatif, meningkatkan daya fokus anak dalam mengerjakan tugas (menggambar), meningkatkan kesabaran, dapat melakukan manajemen emosi dengan baik, meningkatkan kemampuan komunikasi secara nonverbal (mencoret, mewarna, menyampaikan isi hati atau keinginan, pesan dan harapan), menyalurkan hobi atau kegemaran, mengembangkan bakat dan talenta anak dalam menggambar, mengembangkan kemampuan dasar untuk melukis, sarana memecahkan masalah bagi anak melalui cara yang kreatif, dan meningkatkan kepercayaan diri dan lainlain.

Selain dari indiktor diatas dan sesuai dengan proses penelitian yang telah dilakukan, untuk guru juga menjadi peranan yang sangat penting. Bagaimana guru menciptakan suasana belajar yang baik dan menarik bagi anak salah satunya dalam menerapkan model Atik pada anak usia dini. Sesuai dengan pendapat (Suryana, 2016) mengatakan bahwa baik guru maupun oangtua harus membimbing dan memperhatikan anak menggambar, karena dengan menggambar adalah suatu cara untuk mendorong perkembangan fisik, sosial, emosional, motorik dan kognitif anak.

Ada beberapa hal yang dilakukan guru untuk meningkatkan kemampuan anak dalam menggambar yang sudah dilaksanakan peneliti antara lain: mewarnai gambar tanpa harus keluar garis tepi, menghubungkan garis-garis hingga mencapai bentuk tertentu, dan menggambar sederhana. Selain itu guru juga mengajarkan bagaimana anak belajar mekanisme kontrol pensil, cara memegang pensil, dan kecepatan menulis. Sesuai dengan pendapat (Muarifah \& Nurkhasanah, 2019) Aktivitas motorik halus dimaknai untuk membentuk dan mengembangkan kepribadian anak agar kemampuan logika dan emosinya bertambah seimbang. Secara psikologis anak menggambar berarti mengungkapkan gagasan dan emosinya, apa yang dipikir dan yang dirasa dalam suatu bentuk yang ada pada gambar, maka dengan melihat hasil temuan penelitian yang menunjukkan adanya peningkatan kemampuan menggambar diawali konsep membuat garis dan gambar sederhana.

Dengan mengacu pada pernyataan yang dikemukakan oleh (Nasution et al., 2019) yang menyatakan bahwa media, metode maupun model pembelajaran yang menarik merupakan segala sesuatu yang dapat digunakan untuk menyampaikan pesan sehingga dapat merangsang pikiran, perasaan, minat dan perhatian anak sedemikian rupa sehingga proses belajar mengajar dapat terjadi. Dengan melihat hasil temuan penelitian yang 
menunjukkan adanya peningkatan kemampuan menggambar anak melalui model ATIK dengan beberapa metode pembelajaran yang diajarkan pada anak.

Berdasarkan hal di atas, upaya untuk meningkatkan kreatifitas ataupun imajinasi anak dapat dilakukan dengan banyak cara baik dengan metode, model ataupun media, seperti penelitian yang sudah dilaksanakan peneliti dengan model ATIK. Selain itu juga diharapkan kemampuan guru dalam menerapkan model ATIK dalam proses pembelajaran untuk meningkatkan kompetensi menggambar anak Taman Kanak-kanak di kota Bekasi.

\section{SIMPULAN}

Pembelajaran menggambar dengan model ATIK terbukti efektif dalam meningkatkan kompetensi menggambar pada anak TK di Kota Bekasi. Dari hasil penelitian ini model ATIK tidak hanya dapat digunakan di lokasi penelitian saja, namun dapat dimanfaatkan dan diterapkan baik di dalam kota Bekasi maupun di luar kota Bekasi dalam upaya untuk meningkatkan kompetensi anak dalam menggambar untuk anak usia TK.

\section{UCAPAN TERIMA KASIH}

Terima kasih disampaikan kepada semua pihak yang telah memberikan dukungan dan motivasi sehingga hasil penelitian ini dapat terpublikasi. Kepada lembaga Universitas Panca Sakti Bekasi, TK Putra XII, TK Widya Bakti, TK Baiturahman dan TK Amiraserta. Terima kasih juga disampaikan kepada editorial board Jurnal Obsesi: Jurnal Pendidikan Anak Usia Dini yang telah membantu mempublikasikan artikel ini.

\section{DAFTAR PUSTAKA}

Abubakar Baraja. (2008). Psikologi Perkembangan (pp. 112-113). Studia Press.

Arifin, Z. (2011). Konsep dan Model Pengembangan Kurikulum (p. 137). Remaja Rosda Karya.

Bruce R. Joyce, Bruce R Joyce, E. C. (2015). Models of Teaching. Pearson.

CA Ellwood. (1901). The Theory of Imitation in Social Psychology. The American Jornal of Sociology, VI(6), 721-741.

Carina Girvan, Claire Conneely, B. T. (2016). Extending Experiental Learning in Teacher Professional Development. Teaching and Teacher Education, 129-139. https://doi.org/http://dx.doi.org/10.1016/j.tate.2016.04.009

Ditha Prasanti, \& Dinda Rakhma Fitriani. (2018). Pembentukan Karakter Anak Usia Dini: Keluarga, Sekolah, Dan Komunitas. Program Studi Ilmu Komunikasi Fakultas Ilmu Komunikasi Universitas Padjadjaran Studi Ilmu Komunikasi Fakultas Ilmu Komunikasi Universitas Gunadharma, 2(1), 13-19.

Dkk, S. A. (2011). Perkembangan dan Konsep Dasar Pengembangan Anak Usia Dini (p. 1.3). Universitas Terbuka.

Eshun, E. F., Touphic, Mohammed, A., \& Appiah, E. (2018). Exploring the impact of pedagogical strategies in drawing instruction on drawing skills satisfaction: A case study on Ghanaian communication design students. International Journal of Innovation, Creativity and Change, 4(2), 104-122.

Hajar Paramadhi, E. S. (2011). Seni Keterampilan Anak (p. 2.5). Universitas Terbuka Jakarta.

Hartati, S. (2005). Perkembangan Belajar Pada Anak Usia Dini. Departemen Pendidkan Nasional Direktorat Jenderal Pendidikan Tinggi, Direktorat Pembinaan Pendidikan Tenaga KependidiKan dan Ketenagaan Perguruan Tnggi.

Loeloek Endah Poerwati. (2013). Penduan Memahami Kurikulum 2013 (1st ed.). Prestasi Pustaka.

Loyd Mataka, R. T. (2020). A Multistep Inquiry Approach to Improve Pre-Service Elementary Teachers' Conceptual Understanding. International Journal of Research in Education and 
Science, 6(1), 86-99.

Majid, A. (2013). Strategi Pembelajaran. PT Remaja Rosdakarya.

Masitoh dkk. (2005). Pendekatan Belajar Aktif di Taman Kanak-kanak. Departemen Pendidkan Nasional Direktorat Jenderal Pendidikan Tinggi, Direktorat Pembinaan Pendidikan Tenaga KependidiKan dan Ketenagaan Perguruan Tnggi.

Masitoh, O. S. dan H. D. (2005). Pendekatan Belajar Aktif di Taman Kanak-kanak (p. 158). Departemen Pendidkan Nasional Direktorat Jenderal Pendidikan Tinggi, Direktorat Pembinaan Pendidikan Tenaga KependidiKan dan Ketenagaan Perguruan Tnggi.

Muarifah, A., \& Nurkhasanah, N. (2019). Identifikasi Keterampilan Motorik Halus Anak. Journal of Early Childhood Care and Education, 2(1), 14.

Mulayasa, E. (2003). Kurikulum Berbasis Kompetensi (p. 38). Remaja Rosda Karya.

Nasution, N., Yaswinda, Y., \& Maulana, I. (2019). Analisis Pembelajaran Berhitung melalui Media Prisma Pintar pada Anak Usia Dini. Jurnal Obsesi : Jurnal Pendidikan Anak Usia Dini, 4(1), 240. https://doi.org/10.31004/obsesi.v4i1.311

Nusa Putra. (2013). Research \& Development (p. 87). Raja Grafindo Persada.

Patricia Giardiello, Joanne McNulty, B. A. (2013). Observation, Assessment and Planning Practice in a Children's Centre. Child Care in Practice, 19, 118-157. https:/ / doi.org/10.1080/13575279.2012.743871

Prasetyo. (2017). Jurnal Imajinasi. Jurnal Imajinasi, XI(1), 69-76.

Sugiyono. (2008). Metode Peneltian Kuantitatif Kualitatif dan R \& D. Alfabeta Bandung.

Suryana, D. (2016). Pendidikan Anak Usia Dini: Stimulasi \& Aspek Perkembangan Anak. Prenada Media.

Tahel, F., \& Ginting, E. (2018). Penerapan Aplikasi Flash Dalam Media Pembelajaran Mewarnai Gambar Untuk Meningkatkan Motorik Halus. Jurnal Informatika Kaputama(JIK), 2(1), 34-43.

Watini, S. (2019a). Implementasi Model Pembelajaran Sentra pada TK Labschool STAI Bani Saleh Bekasi. Jurnal Obsesi: Jurnal Pendidikan Anak Usia Dini, 4(1), 110. https:// doi.org/10.31004/obsesi.v4i1.190

Watini, S. (2019b). Pendekatan Kontekstual dalam Meningkatkan Hasil Belajar Sains pada Anak Usia Dini. Jurnal Obsesi: Jurnal Pendidikan Anak Usia Dini, 3(1), 82. https:// doi.org/10.31004/obsesi.v3i1.111

Watini, S. (2020). Implementation of Asyik Play Model In Enhancing Character Value of Implementation of Asyik Play Model In Enhancing Character Value of Early Childhood. https:// doi.org/10.1088/1742-6596/1477/4/042055

Watini, S., \& Efendy, H. (2018). The Playing Method "ASYIK" Based on Multiple Intelligence in Learning Science Process at The Early Childhood Education Program (PAUD) Age 5-6 Years. Journal of Studies in Education, 8(1), 51. https:// doi.org/10.5296/jse.v8i1.12108 